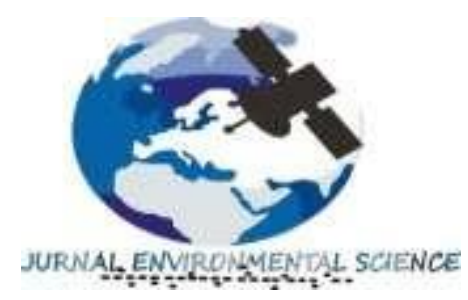

Jurnal Environmental Science

Volume 2 Nomor 2 April 2020

p-ISSN : 2654-4490 dan e-ISSN : 2654-9085

Homepage at : ojs.unm.ac.id/JES

E-mail:jes@unm.ac.id

\title{
STUDI TINGKAT PENGETAHUAN KEBENCANAAN TERHADAP SIKAP KESIAPSIAGAAN MASYARAKAT DALAM MENGHADAPI BENCANA TANAH LONGSOR DI KECAMATAN PARANGLOE KABUPATEN GOWA TAHUN 2019
}

\author{
Sri Rahmadhani Nur Alam ${ }^{1}$, Erman Syarif $^{2}$ \\ ${ }^{12}$ Jurusan Geografi, Fakultas Matematika dan Ilmu Pengetahuan Alam, \\ Universitas Negeri Makassar, Indonesia. \\ Email: srirahmadhania@gmai.com ${ }^{1}$, emankgiman@gmail.com²
}

\begin{abstract}
Indonesia is one of the countries prone to landslides. This can disrupt people's lives and threaten safety. The objectives of this study are: 1) Knowing the level of knowledge of community disaster in the face of landslides in Lonjoboko Village, 2) Knowing people's behavior towards preparedness in the face of landslides in Lonjoboko Village, 3) Knowing the relationship between the level of disaster knowledge on preparedness attitudes in the face of landslides in the village of Lonjoboko. Samples were taken using Simple Random Sampling Technique, as many as 97 people from 2,886 residents. Research variables include knowledge of disaster and preparedness attitudes. Data collection techniques used are: Documentation, Questionnaire, and Observation. Data analysis was carried out with a descriptive percentage analysis method to describe all variables, simple linear regression analysis to determine whether there was an influence of variables on other variables, and to perform normality tests using the Kolmogorov smirnov method and normal plot graph method. Based on the results of the research on the level of disaster knowledge, the average score of the respondents was 65.32\% which was included in the high category. Community behavior towards preparedness in the face of landslides in Lonjoboko Village is in the poor category, because people only think about survival, so they do not take the time to prepare their vigilance against disasters
\end{abstract}

Keywords: Knowledge Of Disaster, Preparedness, Landslide Disaster

\begin{abstract}
ABSTRAK
Indonesia merupakan salah satu negara yang rawan mengalami bencana longsor. Hal tersebut dapat mengganggu kehidupan masyarakat dan mengancam keselamatan. Tujuan penelitian ini yaitu: 1) Mengetahui tingkat pengetahuan kebencanaan masyarakat dalam menghadapi bencana tanah longsor di Desa Lonjoboko, 2) Mengetahui perilaku masyarakat terhadap adanya sikap kesiapsiagaan dalam menghadapi bencana tanah longsor di Desa Lonjoboko, 3) Mengetahui hubungan antara tingkat pengetahuan kebencanaan terhadap sikap kesiapsiagaan dalam menghadapi bencana tanah longsor di Desa Lonjoboko. Sampel diambil menggunakan Teknik Simple Random Sampling, sebanyak 97 orang dari 2.886 penduduk. Teknik pengumpulan data yang digunakan yaitu: Dokumentasi, Kuesioner, dan Observasi. Analisis data dilakukan dengan metode analisis deskriptif kuantitatif, analisis regresi linier sederhana untuk mengetahui ada tidaknya pengaruh variabel terhadap variabel lainnya, dan melakukan uji normalitas menggunakan metode Kolmogorov smirnov dan metode grafik. Berdasarkan hasil penelitian tingkat pengetahuan kebencanaan didapatkan nilai rata-rata responden $65,32 \%$ yang termasuk dalam kategori tinggi. Perilaku masyarakat terhadap adanya sikap kesiapsiagaan dalam menghadapi bencana tanah longsor di Desa Lonjoboko berada dikategori kurang baik, karena masyarakatnya hanya memikirkan untuk bertahan hidup, sehingga tidak meluangkan waktu untuk mempersiapkan kewaspadaannya terhadap bencana..
\end{abstract}

Kata Kunci: Pengetahuan Kebencanaan, Kesiapsiagaan, Bencana Tanah Longsor 


\section{PENDAHULUAN}

Bencana tanah longsor merupakan salah satu bencana alam yang sering terjadi di Indonesia dan umumnya sering terjadi di wilayah pegunungan serta pada musim hujan.

Rawan bencana adalah kondisi atau karakteristik geologis, biologis, hidrologis, klimatologis, geografis, sosial, budaya, politik, ekonomi, dan teknologi pada suatu wilayah untuk jangka waktu tertentu yang mengurangi kemampuan mencegah, meredam, mencapai kesiapan, dan mengurangi kemampuan untuk menanggapi dampak buruk bahaya tertentu.

Di Sulawesi Selatan, ada sembilan potensi bencana yang akan melanda 18 Kecamatan di Kabupaten Gowa yang dikemukakan oleh Badan Penanggulangan Bencana Daerah Kabupaten Gowa. Dari ke-sembilan bencana tersebut, yang paling sering terjadi adalah longsor dan salah satu kecamatan yang memiliki potensi tinggi untuk terkena bencana longsor yaitu Kecamatan Parangloe.

Mempertimbangkan hal-hal mengenai risiko bencana tanah longsor yang cukup besar dampaknya dan pentingnya upaya penanggulangan bencana, maka sangat diperlukan kesadaran dari masyarakat untuk dapat ikut serta dalam upaya penanggulangan bencana secara non fisik. Perlu ada suatu pemahaman dari masyarakat tentang cara-cara menghadapi risiko bencana tanah longsor yang sewaktu-waktu dapat mengancam keselamatan mereka. Peningkatan dampak bencana longsor tidak terlepas dari peningkatan jumlah penduduk dan aktivitas dari masyarakat dalam mengelola lingkungan, sehingga dalam hal ini peneliti tertarik untuk mengkaji fenomena ini dalam sebuah penelitian.

\section{METODE}

Untuk memperoleh data yang kongkrit dan teratur, maka penempatan lokasi atau daerah penelitian yang tepat sangat menentukan. Penelitian ini dilakukan di Desa Lonjoboko Kecamatan Parangloe Kabupaten Gowa pada bulan Mei 2019.

Sampel dipilih menggunakan Metode Probability Sampling, yaitu Teknik Simple Random Sampling dengan pertimbangan bahwa populasi penelitian ini adalah masyarakat umum, dan setiap individu mempunyai kesempatan yang sama untuk dipilih sebagai sampel. Jumlah penduduk di Desa Lonjoboko Kecamatan Parangloe menurut data BPS Kecamatan Parangloe tahun 2017 adalah 2.886 penduduk, sehingga dapat ditentukan besar sampel yang akan dijadikan obyek penelitian adalah sebagai berikut.

$$
\begin{aligned}
& \mathrm{n}=\frac{\mathrm{N}}{\mathrm{Nd}^{2}+1} \\
& \mathrm{n}=\frac{2886}{2886(10 \%)^{2}+1} \\
& \mathrm{n}=\frac{2886}{29,86} \\
& \mathrm{n}=96,65 \\
& \mathrm{n}=97
\end{aligned}
$$

Jadi, jumlah sampel yang akan diteliti adalah 97 penduduk.

\section{Teknik Pengumpulan Data}

\section{Observasi}

Observasi yang dilakukan dalam penelitian ini dengan melakukan pengamatan lapangan untuk mendapatkan data yang aktual dan langsung melakukan pengamatan pada lokasi penelitian.

2. Dokumentasi

Metode dokumentasi merupakan metode yang digunakan untuk mengambil data-data hasil observasi di Kecamatan Parangloe. Dalam hasil dokumentasi ini data-data yang di ambil berupa dokumen data kependudukan, dokumen pendukung lainnya, serta gambar maupun foto-foto yang diperoleh dari kegiatan observasi, wawancara, dan kegiatan lain yang mendukung dan menguatkan penelitian.

\section{Kuesioner}

Kuesioner merupakan pertanyaan tertulis yang digunakan untuk memperoleh informasi dari responden di Kecamatan Parangloe. Kuesioner ini digunakan untuk mengetahui mitigasi dan antisipasi masyarakat dalam menghadapi bencana tanah longsor 


\section{Teknik Analisis Data}

1. Menguji validitas data dan reliabilitas data menggunakan aplikasi SPSS. Sebuah instrumen dikatakan valid apabila mampu mengukur apa yang diinginkan dan dapat mengungkap data dari variabel yang diteliti secara tepat. Instrumen dikatakan valid jika nilai Pearson Correlation $>r$ tabel dan tingkat signifikasi dari masing-masing skor butir-butir pertanyaan $<0,05(5 \%)$ berarti dikatakan valid. Sebaliknya jika diperoleh $>0,05$ maka instrumen dikatakan tidak valid.

2. Uji Normalitas data menggunakan metode Kolmogorov smirnov dan grafik normal plot di aplikasi SPSS. Metode pengujian normal tidaknya distribusi data dilakukan dengan melihat nilai signifikan variabel, jika lebih besar dari alpha 5\% maka menunjukkan distribusi data normal. Sedangkan dengan melihat grafik normal plot, jika distribusi data residual normal, maka garis yang menggambarkan data sesungguhnya akan mengikuti garis diagonalnya.

3. Menguji hubungan dua variabel dengan menggunakan Analisis Regresi Linier Sederhana. Secara umum rumus persamaan regresi linear sederhana adalah $Y=a+b X$. Dimana, y adalah variabel dependent, $\mathrm{x}$ adalah variabel independent, a adalah konstanta, dan $\mathrm{b}$ adalah koefisien regresi.

\section{HASIL DAN PEMBAHASAN \\ Hasil}

\section{Uji validitas}

Tabel 1. Hasil Uji Validitas Tingkat Pengetahuan Kebencanaan

\begin{tabular}{|c|c|c|c|}
\hline Item & Sig. 2 tailed & Signifikansi & Keterangan \\
\hline S1 & 0,000 & $<0,05$ & Valid \\
\hline S2 & 0,000 & $<0,05$ & Valid \\
\hline S3 & 0,002 & $<0,05$ & Valid \\
\hline S4 & 0,000 & $<0,05$ & Valid \\
\hline S5 & 0,000 & $<0,05$ & Valid \\
\hline S6 & 0,000 & $<0,05$ & Valid \\
\hline S7 & 0,000 & $<0,05$ & Valid \\
\hline S8 & 0,000 & $<0,05$ & Valid \\
\hline S9 & 0,000 & $<0,05$ & Valid \\
\hline S1O & 0,000 & $<0,05$ & Valid \\
\hline S11 & 0,000 & $<0,05$ & Valid \\
\hline S12 & 0,000 & $<0,05$ & Valid \\
\hline S13 & 0,046 & $<0,05$ & Valid \\
\hline S14 & 0,000 & $<0,05$ & Valid \\
\hline S15 & 0,027 & $<0,05$ & Valid \\
\hline S16 & 0,015 & $<0,05$ & Valid \\
\hline S17 & 0,000 & $<0,05$ & Valid \\
\hline S18 & 0,007 & $<0,05$ & Valid \\
\hline S19 & 0,019 & $<0,05$ & Valid \\
\hline S2O & 0,003 & $<0,05$ & Valid \\
\hline S21 & 0,000 & $<0,05$ & Valid \\
\hline S22 & 0,001 & $<0,05$ & Valid \\
\hline S23 & 0,013 & $<0,05$ & Valid \\
\hline S24 & 0,000 & $<0,05$ & Valid \\
\hline S25 & 0,000 & $<0,05$ & Valid \\
\hline & & & \\
\hline
\end{tabular}

Sumber : Hasil Olah Data SPSS, 2019

Berdasarkan data pada Tabel 1 terlihat bahwa nilai rata-rata signifikansi dari variabel pengetahuan kebencanaan semuanya kurang dari dari 0,05 . Dengan demikian, dapat dinyatakan bahwa seluruh butir pertanyaan untuk variabel pengetahuan kebencanaan adalah valid. 
Tabel 2. Hasil Uji Validitas Sikap Kesiapsiagaan

\begin{tabular}{|c|c|c|c|}
\hline Item & Sig. 2 tailed & Signifikansi & Keterangan \\
\hline S1 & 0,011 & $<0,05$ & Valid \\
\hline S2 & 0,000 & $<0,05$ & Valid \\
\hline S3 & 0,002 & $<0,05$ & Valid \\
\hline S4 & 0,001 & $<0,05$ & Valid \\
\hline S5 & 0,000 & $<0,05$ & Valid \\
\hline S6 & 0,000 & $<0,05$ & Valid \\
\hline S7 & 0,001 & $<0,05$ & Valid \\
\hline S8 & 0,000 & $<0,05$ & Valid \\
\hline S9 & 0,012 & $<0,05$ & Valid \\
\hline S10 & 0,013 & $<0,05$ & Valid \\
\hline S11 & 0,039 & $<0,05$ & Valid \\
\hline S12 & 0,001 & $<0,05$ & Valid \\
\hline S13 & 0,027 & $<0,05$ & Valid \\
\hline S14 & 0,000 & $<0,05$ & Valid \\
\hline S15 & 0,001 & $<0,05$ & Valid \\
\hline S16 & 0,008 & $<0,05$ & Valid \\
\hline S17 & 0,000 & $<0,05$ & Valid \\
\hline S18 & 0,000 & $<0,05$ & Valid \\
\hline S19 & 0,022 & $<0,05$ & Valid \\
\hline S20 & 0,002 & $<0,05$ & Valid \\
\hline S21 & 0,035 & $<0,05$ & Valid \\
\hline S22 & 0,006 & $<0,05$ & Valid \\
\hline S23 & 0,002 & $<0,05$ & Valid \\
\hline S24 & 0,002 & $<0,05$ & Valid \\
\hline S25 & 0,004 & $<0,05$ & Valid \\
\hline Sumber & Hasil Olah Data SPSS 2019 \\
\hline
\end{tabular}

Berdasarkan data pada Tabel 2 terlihat bahwa nilai rata-rata signifikansi dari variabel pengetahuan kebencanaan semuanya kurang dari dari 0,05. Dengan demikian, dapat dinyatakan bahwa seluruh butir pertanyaan untuk variabel pengetahuan kebencanaan adalah valid.

\section{Uji Reliabilitas}

Tabel 3. Hasil Uji Coba Reliabilitas Tingkat Pengetahuan Kebencanaan

\begin{tabular}{|c|c|c|}
\hline \multicolumn{3}{|c|}{ Reliability Statistics } \\
\hline Cronbach's Alpha & $\begin{array}{l}\text { Cronbach's Alpha Based on } \\
\text { Standardized Items }\end{array}$ & $\mathrm{N}$ \\
\hline .682 & .799 & 25 \\
\hline
\end{tabular}

Berdasarkan data pada Tabel 3 terlihat bahwa nilai Cronbach's Alpha $=0,682$ lebih besar dari 0,60 . Dengan demikian dapat dikatakan bahwa semua butir pertanyaan untuk variabel kebijakan produk adalah reliabel.

Tabel 4. Hasil Uji Coba Reliabilitas Sikap Kesiapsiagaan

\begin{tabular}{|c|c|c|}
\hline \multicolumn{3}{|c|}{ Reliability Statistics } \\
\hline & $\begin{array}{c}\text { Cronbach's Alpha Based on } \\
\text { Standardized Items }\end{array}$ & $\begin{array}{c}\text { N of } \\
\text { Items }\end{array}$ \\
\hline .663 & .671 & 25 \\
\hline Sumber : Hasil Olah Data SPSS, & 2019
\end{tabular}

Berdasarkan data pada Tabel 4 terlihat bahwa nilai Cronbach's Alpha $=0,663$ lebih besar dari 0,60 . Dengan demikian dapat dikatakan bahwa semua butir pertanyaan untuk variabel kebijakan produk adalah reliabel. 


\section{Uji Normalitas}

a) Metode Kolmogorov Smirnov

Tabel 5. Hasil Uji Normalitas Data Menggunakan Metode Kolmogorov Smirnov

\begin{tabular}{|c|c|c|c|}
\hline \multicolumn{4}{|c|}{ One-Sample Kolmogorov-Smirnov Test } \\
\hline & & Sikap Kesiapsiagaan & Pengetahuan \\
\hline $\mathrm{N}$ & & 97 & 97 \\
\hline Normal & Mean & 62.2268 & 65.3196 \\
\hline $\begin{array}{l}\text { Parameter } \\
\mathrm{s}^{\mathrm{a}, \mathrm{b}}\end{array}$ & $\begin{array}{l}\text { Std. } \\
\text { Deviation }\end{array}$ & 6.56776 & 5.32202 \\
\hline Most & Absolute & .079 & .095 \\
\hline Extreme & Positive & .038 & .060 \\
\hline Difference & Negative & -.079 & -.095 \\
\hline Kolmogoro & v-Smirnov & .774 & .932 \\
\hline Asymp. Sig & (2-tailed) & .586 & .350 \\
\hline
\end{tabular}

Tabel 5 di atas menerangkan bahwa nilai sig. untuk sikap kesiapsiagaan adalah 0,586 dan nilai sig untuk pengetahuan kebencanaan adalah 0,530. Dimana arti dari nilai signifikansi yang di dapatkan tersebut berdistribusi normal karna nilai interpretasi tersebut berada di atas 0,05 .

b) Metode Grafik

Metode grafik yang digunakan untuk menguji normalitas data dalam penelitian ini menggunakan grafik histogram dan grafik normal plot.

1) Grafik Histogram

Gambar 1. Grafik Histogram Penelitian

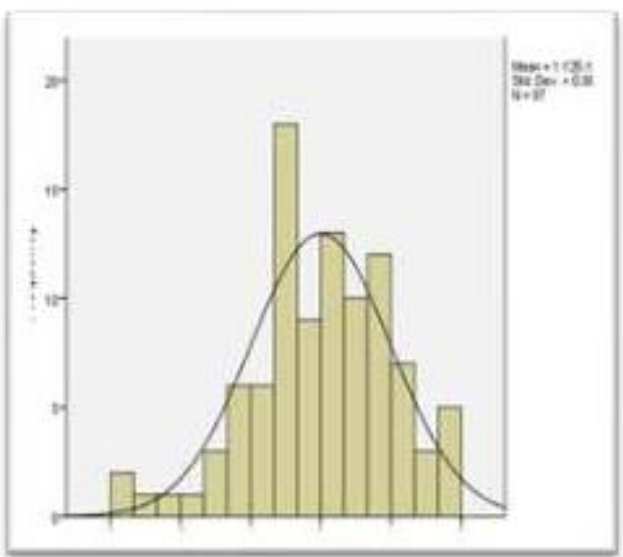

Sumber : Hasil Olah Data SPSS, 2019

Berdasarkan tampilan output chart di atas, grafik histogram tersebut memberikan pola distribusi yang melenceng ke kanan yang artinya adalah data berdistribusi normal.

2) Grafik Normal Plot

Gambar 2. Grafik Histogram Penelitian

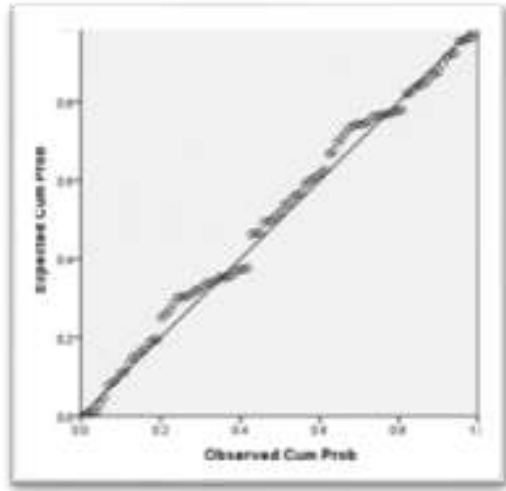

Sumber : Hasil Olah Data SPSS, 2019 
Pada gambar grafik normal plot di atas memperlihatkan titik-titik mengikuti dan mendekati garis diagonalnya sehingga dapat disimpulkan bahwa model regresi memenuhi asumsi normalitas.

\section{Tingkat Pengetahuan dan Sikap Kesiapsiagaan Masyarakat Desa Lonjoboko}

a. Aspek Pengetahuan

Sebanyak 68 orang $(70,11 \%)$ masyarakat di Desa Lonjoboko tergolong berpengetahuan tinggi dalam hal pengetahuan kebencanaan tanah longsor. Sementara 29 orang $(29,89 \%)$ masyarakat berpengetahuan rendah. Sehingga dipastikan bahwa masyarakat Desa Lonjoboko memiliki pengetahuan dalam kategori tinggi. Hal ini dapat dilihat dari karakteristik pendidikan responden, yang tamat sekolah dan telah melalui berbagai jenjang pendidikan tinggi. Sedangkan ada juga masyarkatnya yang tidak tamat ataupun tidak sekolah sehingga tidak memiliki pengetauan tentang bencana tanah longsor.

b. Aspek Sikap Kesiapsiagaan

Sebanyak 48 orang memiliki sikap yang baik terhadap kesiapsiagaan. Hal ini dikarenakan sebagian dari mereka pernah mengikuti penyuluhan atau sosialisasi tentang bahaya tanah longsor. Sedangkan ada 49 orang yang memiliki sikap kurang baik terhadap sikap kesiapsiagaan. Dikarenakan mereka, memiliki sikap acuh tak acuh. Meskipun mereka mengingkan yang lebih baik untuk lingkungannya. Tetapi masyarakatnya lebih memilih untuk melakukan aktivitasnya untuk mempertahankan hidup karena kondisi ekonomi yang terbatas, sehingga mereka tidak pernah sekalipun mengikuti kegiatan yang diadakan oleh pemerintah.

\section{Analisis Regresi Linier Sederhana}

Secara umum rumus persamaan regresi linear sederhana adalah $Y=a+b X$. Sementara untuk mengetahui nilai koefisient regresi tersebut dapat berpedoman pada output yang berada pada tabel coefficients berikut.

Tabel 6. Koefisien Hasil Regresi Linier Sederhana

\begin{tabular}{|c|c|c|c|c|c|}
\hline \multicolumn{6}{|c|}{ Coefficients $^{\mathrm{a}}$} \\
\hline \multirow{2}{*}{ Model } & \multicolumn{2}{|c|}{$\begin{array}{l}\text { Unstandardized } \\
\text { Coefficients }\end{array}$} & \multirow{2}{*}{\begin{tabular}{|c|}
$\begin{array}{c}\text { Standar } \\
\text { dized } \\
\text { Coeffici } \\
\text { ents }\end{array}$ \\
Beta \\
\end{tabular}} & \multirow[t]{2}{*}{$\mathrm{t}$} & \multirow[t]{2}{*}{ Sig. } \\
\hline & B & $\begin{array}{c}\text { Std. } \\
\text { Error }\end{array}$ & & & \\
\hline (Constant) & 89.205 & 7.819 & & 11.409 & .000 \\
\hline${ }^{1}$ Pengetahuan & -.413 & .119 & -.335 & -3.462 & .001 \\
\hline
\end{tabular}

Sumber : Hasil Olah Data SPSS, 2019

Nilai a adalah angka konstan dari unstandardized coefficients. Dalam kasus ini nilai a sebesar 89,205 . Angka ini merupakan konstan yang mempunyai arti bahwa jika tidak ada pengetahuan, maka nilai konsisten sikap kesiapsiagaan adalah sebesar 89,205.

Nilai $\mathrm{b}$ adalah koefisien regresi. Nilainya sebesar 0,413. Angka ini mengandung arti bahwa setiap penambahan 1\% tingkat pengetahuan maka sikap kesiapsiagaan akan meningkat sebesar 0,413. Karena nilai koefisien regresi bernilai minus, maka dengan demikian dapat dikatakan bahwa tingkat pengetahuan berpengaruh positif terhadap sikap kesiapsiagaan. Sehingga persamaan regresinya adalah $\mathrm{Y}=89,205+0,413 \mathrm{X}$.

Untuk memastikan apakah koefisien regresi tersebut signifikan atau tidak, dapat dilakukan dengan membandingkan nilai signifikan (Sig.) dengan probabilitas 0,05 atau dengan cara lain yakni membandingkan nilai t hitung dengan t tabel. Menggunakan perbandingan nilai signifikan, maka dilihat dari tabel 6 nilai (Sig.) 0,001 lebih kecil dari nilai probabilitasnya sebesar 0,05, sehingga dapat dikatakan tingkat pengetahuan memiliki pengaruh terhadap sikap kesiapsiagaan warga dalam menghadapi bencana tanah longsor.

\section{Pembahasan}

\section{Tingkat Pengetahuan Warga Dalam Menghadapi Bencana Tanah Longsor}

Pengetahuan adalah akumulasi dari pengalaman-pengalaman yang dialami manusia, yang diperolehnya melalui cara membaca, melihat, mendengar, bahkan merasakan berbagai objek social yang terjadi disepanjang hidupnya. Pengetahuan yang terbentuk dari pengalaman-pengalaman dapat saja terjadi secara langsung maupun tidak langsung.

Berdasarkan penelitian ini diperoleh hasil bahwa warga Desa Lonjoboko telah menjawab pertanyaan dan pernyataan tentang pengetahuan kebencanaan. Ditinjau dari sisi kualitas jawaban pada 
setiap item pernyataan yang berkaitan dengan pengetahuan responden tentang bencana tanah longsor, didapatkan nilai rata-rata skor total dari jawaban yang diberikan responden adalah sebesar 65,32 atau $65,32 \%$ dari skor total maksimal sebesar 100 (nilai total skor maksimal didapatkan dengan asumsi seluruh responden memberikan jawaban dengan skor tertinggi pada tiap item soal yaitu (4). Presentase tersebut mengindikasikan bahwa tingkat pengetahuan kebencanaan tentang tanah longsor di Desa Lonjoboko masuk dalam kategori tingkat tinggi.

\section{Perilaku Masyarakat Terhadap Adanya Sikap Kesiapsiagaan Menghadapi Bencana Tanah Longsor}

Perilaku masyarakat terhadap adanya sikap kesiapsiagaan menghadapi bencana tanah longsor di Desa Lonjoboko Kecamatan Parangloe dapat dikategorikan kurang baik dari hasil penelitian yang dilakukan. Wujud perilaku masyarakat yang kurang baik, dapat dilihat pada jawaban yang diberikan oleh responden pada item-item pertanyaan pada lembar kuesioner. Hasil studi menunjukkan, sebagian besar masyarakat hanya ingin yang lebih baik untuk lingkungannya, akan tetapi sebagian besar masyarakat tersebut kurang aktif dalam ikut serta pada sosialisasi dan penyuluhan-penyuluhan yang dilakukan oleh pemerintah setempat.

Wujud perilaku masyarakat lainnya yang jelas nampak di daerah penelitian terutama pada aspek jenis tata guna lahan yang belum ramah bencana tanah longsor, seperti lahan persawahan, tegalan, dan tambang pasir banyak ditemui di sekitar daerah rawan bencana tanah longsor. Pada aspek mendirikan bangunan atau fasilitas fisik, banyak ditemui letak bangunan rumah maupun fasilitas fisik lainnya di sekitar lereng dan sempadan sungai di daerah penelitian. Memang terdapat perilaku positif yang banyak dilakukan oleh masyarakat terhadap upaya pengurangan risiko bencana tanah longsor yakni menanam pohon di sekitar rumah dan lereng perbukitan atau pegunungan. Masyarakatnya juga selalu waspada setiap kali terjadi hujan lebat yang terjadi secara terus-menerus. Namun hal tersebut belum sepenuhnya berpengaruh besar terhadap hasil upaya pengurangan risiko bencana tanah longsor.

\section{Hubungan Antara Tingkat Pengetahuan Dengan Sikap Kesiapsiagaan Menghadapi Bencana Tanah Longsor}

Berdasarkan data hasil analisis regresi linear sederhana yang di dapat melalui program SPSS menunjukkan bahwa pengetahuan kebencanaan memiliki tingkat signifikansi ( $p$-value) sebesar 0,001 atau kurang dari tingkat signifikansi yang dipersyaratkan yakni sebesar 0,05. Hal ini berarti, koefisien regresi pengetahuan kebencanaan memiliki pengaruh yang signifikan terhadap sikap kesiapsiagaan. Dan dengan melihat persamaan regresinya $\mathrm{Y}=89,205+0,413 \mathrm{X}$, maka merujuk pada persamaan tersebut dapat dikatakan bahwa pengetahuan kebencanaan berpengaruh positif pada sikap kesiapsiagaan yang memiliki nilai koefisien sebesar 89,205. Pengaruh positif ini bermakna semakin tinggi pengetahuan kebencanaan maka akan semakin tinggi pula sikap kesiapsiagaan warga dalam menghadapi bencana tanah longsor.

\section{SIMPULAN DAN SARAN}

Dari hasil penelitian tentang Studi Tingkat Pengetahuan Kebencanaan Terhadap Sikap Kesiapsiagaan Menghadapi Bencana Tanah Longsor Di Desa Lonjoboko Kecamatan Parangloe Kabupaten Gowa Tahun 2019 dapat disimpulkan sebagai berikut; (1) Tingkat pengetahuan kebencanaan warga di Desa Lonjoboko berada dalam kategori tinggi. Masyarakatnya tahu di Desa Lonjoboko cukup sering terjadi bencana tanah longsor. Akan tetapi tidak cukup hanya mengetahui tentang bahaya longsor, masyarakat juga harus tahu tentang sikap siaga dan waspada dalam meminimalisir bahaya tanah longsor, (2) Perilaku masyarakat terhadap adanya sikap kesiapsiagaan menghadapi bencana tanah longsor di Desa Lonjoboko berada pada kategori kurang baik. Hal ini terjadi karena masyarakatnya belum sepenuhnya menunjukkan wujud sikap kesiapsiagaan yang baik, (3) Hasil pengujian analisis regresi, maka ada pengaruh positif pengetahuan kebencanaan terhadap sikap kesiapsiagaan warga dalam menghadapi bencana tanah longsor di Desa Lonjoboko Kecamatan Parangloe Kabupaten Gowa. Hal ini berarti semakin tinggi pengetahuan kebencanaan maka akan semakin tinggi pula sikap kesiapsiagaan warga dalam menghadapi bencana tanah longsor.

Saran yang dapat diberikan terkait dengan pengembangan penelitian ini adalah sebagai berikut ; (1) Bagi peneliti diharapkan mampu menemukan paramater lain dalam melakukan penyelidikan secara rinci terhadap bahaya longsor, (2) Bagi pemerintah pusat diharapkan 
untuk melakukan survei lapangan tiap tahunnya dan melakukan rekayasa teknika terhadap kawasan yang berpotensi longsor, (3) Bagi pemerintah setempat diharapkan untuk melakukan penanggulangan yang lebih efektif, melakukan sosialisasi mengenai tata guna lahan dan informasi bahaya bencana longsor kepada penduduk setempat, (4) Bagi masyarakat, agar tidak mendirikan pemukiman, bercocok tanam, dan melakukan aktivitas tambang di daerah yang terjal.

\section{DAFTAR RUJUKAN}

Alfiani, Nelly. 2017. Tingkat Pengetahuan Masyarakat Suku Bajo Dalam Pengelolaan Sampah di Desa Mola Kabupaten Wakatobi. Skripsi. Makassar: Fakultas Matematika dan Ilmu Pengetahuan Alam Universitas Negeri Makassar

Arif, Firman N. 2015. Analisis Kerawanan Tanah Longsor Untuk Menentukan Upaya Mitigasi Bencana Di Kecamatan Kemiri Kabupaten Purworejo. Skripsi. Semarang : Fakultas Ilmu Sosial, Universitas Negeri Semarang.

Armayani, Andi. 2012. Studi Sifat Fisis Batuan Pada Daerah Rawan Longsor Kecamatan Parangloe Kabupaten Gowa Sulawesi Selatan. Skripsi. Makassar: Fakultas Sains dan Teknologi, Universitas Alauddin Makassar.

Badan Pusat Statistik Kabupaten Gowa. 2018. Kecamatan Parangloe Dalam Angka 2018.

Departemen Energi dan Sumber Daya Mineral. 2006. Pengenalan Gerakan Tanah.

Fajril. 2007. Analisis Sifat Fisis Tanah Pada Daerah Rawan Bencana Tanah Longsor Dengan Menggunakan Geolistrik Tahanan Jenis Tanah di Kecamatan Sinjai Tengah Kabupaten Sinjai. Thesis. Makassar : UNM Press

Ningtyas, B. A. 2015. Pengaruh Pengetahuan Kebencanaan Terhadap Sikap Kesiapsiagaan Warga Dalam Menghadapi Tanah Longsor di Desa Sridadi Kecamatan Sirampoa Kabupaten Brebes Tahun 2014. Skripsi. Semarang : Universitas Negeri Semarang.

Paimin, dkk. 2009. Teknik Mitigasi Bencana Banjir dan Tanah Longsor. Balikpapan : Tropenbos International Programme.

Soemantri, Lili. 2014. Kajian Mitigasi Bencana Longsor Lahan Dengan Menggunakan Teknologi Penginderaan Jauh. Padang : Ikatan Geografi Indonesia.

Undang-Undang Republik Indonesia Nomor 24 Tahun 2007 Tentang Kebencanaan 